\title{
Cancer risk prompts US to curb gene therapy
}

Erika Check, Washington

Children with severe combined immunodeficiency disease (SCID) should not normally be treated with gene therapy because of the associated cancer risk, a US advisory panel says. But it believes that there is insufficient evidence to justify halting similar trials for other conditions.

The treatment for SCID, a disease that disrupts the development of the immune system, had been the only success for gene therapy so far. But the Food and Drug Administration (FDA) suspended US SCID trials and then halted 24 similar trials in January, after two children treated for the condition in a French study developed leukaemia.

Following the ruling on 28 February by the FDA's Biological Response Modifiers Advisory Committee (BRMAC), most of these 24 trials are expected to resume, when each has undergone an FDA safety review.

The BRMAC's decision is largely consistent with that taken earlier this month by the Recombinant DNA Advisory Committee, which advises the National Institutes of Health on trials sponsored by the agency. But the new recommendation has a broader reach, as the FDA regulates all US clinical trials, including those that are privately sponsored.

Although the committee's decision that the therapy should not be used unless there is no other option was widely expected, it still marks a setback for the field of gene therapy.

"The impact of these cases has reverberated in the field in a lot of ways," says Daniel Salomon, outgoing chairman of the BRMAC and a gene-therapy researcher at the Scripps Research Institute in La Jolla, California.

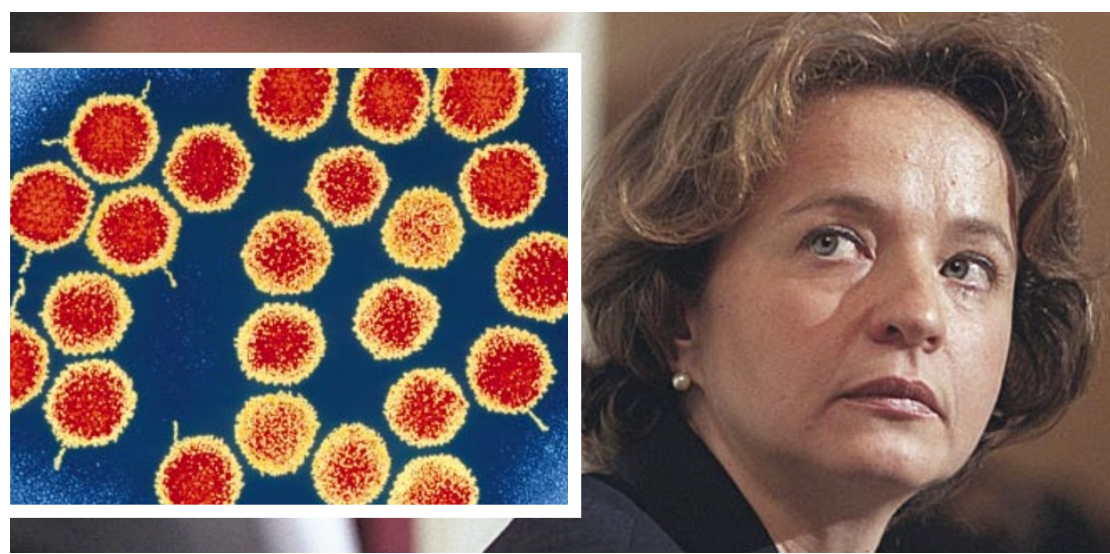

Marina Cavazzana-Calvo has evidence that viral vectors (inset) used in gene therapy could cause cancer.

"The potential for a risk of cancer is going to influence everything we do."

The major question now haunting the field is why the children in the SCID trial led by Alain Fischer at the Necker Hospital for Sick Children in Paris - developed cancer. Most of the available evidence points to the retroviral vector used to shuttle the corrective gene into the children's cells. This is significant because modified retroviruses are often used as the vector in gene therapy.

Scientists now need to find out whether using retroviral vectors in other diseases will also cause cancer - or whether the particular gene being delivered, or the disease being treated, somehow increased the risk for the French SCID trial.

At the 28 February meeting, Fischer's colleague Marina Cavazzana-Calvo showed preliminary evidence that the vector, rather than the gene inserted into it, was responsible for the leukaemia. The evidence is far from definitive, but if it holds up, it would mean that any other retroviral vector could theoretically cause the same problem.

And although only two of ten children treated by Fischer have developed cancer, there are some signs that others could potentially develop the disease (see Nature 421,678; 2003).

In the meantime, private-sector backers of gene therapy are becoming skittish. More than one company has scaled back investment in retroviruses and other vectors that integrate themselves into human DNA.

"There was a lot of hype that there would be clinical therapies using gene therapy by now, and it's logical that there's been a retrenchment," says Salomon. "There are some major issues that the field has to address."

\section{Coal-fired power plant to bury issue of emissions}

\section{Hannah Hoag, Washington}

The United States plans to build a coal-fired power plant that will sequester its carbon dioxide emissions deep underground.

The \$1-billion, ten-year project, called FutureGen, would produce electricity and hydrogen. Financed with federal, private and international funds, it will serve as a working prototype for clean-coal

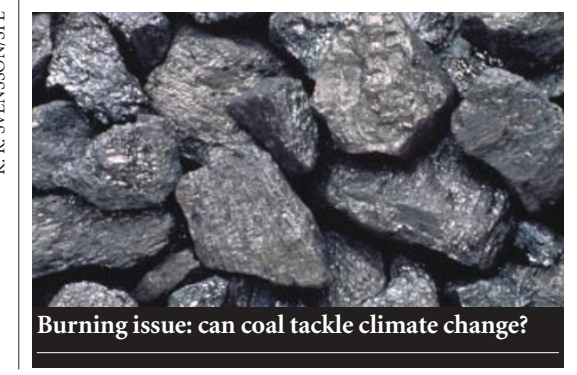

technologies and power production, say officials at the US energy department.

No proposed location and few technical details were provided by energy secretary Spencer Abraham when he announced the plan in Washington on 27 February. A Carbon Sequestration Leadership Forum will be held in Virginia in June to assemble a consortium of industrial and international partners for the project, he said, and details will be planned subsequently. Officials say that the plant will initially sequester $90 \%$ of its carbon dioxide emissions, a figure that may rise to $100 \%$ at a later date.

The initiative is the latest in a string of recent announcements that seem designed to answer criticism that the Bush administration has failed to provide leadership in addressing climate change (see page 1 ).

Some scientists and environmental groups have welcomed FutureGen as a forward-looking project that will help to address climate change in the long term. But critics charge that the scheme's benefits are decades away, and that it will divert money and attention away from short- and medium-term efforts to address the problem of greenhouse-gas emissions.

"The fact that it is not coupled with serious short-term efforts is an indication that this administration does not take climate change seriously," says Cutler Cleveland, director of Boston University's Center for Energy and Environmental Studies.

Uncertainties surround the feasibility of large-scale carbon sequestration. In principle, carbon dioxide could be contained in terrestrial or marine sites. Tests to achieve this are currently under way on a small scale at various sites around the world. 